AKRUAL 5 (2) (2014): 204-221 e-ISSN: 2502-6380

\author{
AKRUAL \\ Jurnal Akuntansi \\ http://fe.unesa.ac.id/ojs/index.php/akrl
}

\title{
PENGARUH KARAKTERISTIK SISTEM INFORMASI AKUNTANSI \\ MANAJEMEN: BROAD SCOPE, TIMELINESS, AGGREGATED, DAN \\ INTEGRATED TERHADAP KINERJA MANAJERIAL UMKM. (STUDI PADA UMKM DI DESA WEDORO, KAB. SIDOARJO)
}

\author{
Susi Handayani \\ Fakultas Ekonomi Universitas Negeri Surabaya \\ Email: susihandayani_76@yahoo.com \\ Hariyati \\ Fakutas Ekonomi Universitas Negeri Surabaya \\ Email: aan_har@yahoo.com
}

Artikel diterima: 15 Januari 2014

Terakhir direvisi: 15 Maret 2014

\begin{abstract}
SMEs need information systems that are reliable and competent entrepreneurial personality that will have an impact on managerial performance. Information reliable accounting system according Chenhall and Morris (1986) is one that has the characteristics of broad scope, timeliness, aggregation and integration. Information management accounting system that is broad scope is information that attention focus, quantification, and time horizon. Timeliness dimension has two sub dimensions, namely the frequency of reporting and speed of reporting. Dimensions aggregate is a summary of information by function, time periods, and the decision model. Integrated information reflects the lack of coordination between segments of one and the other subunits within the organization. This research is quantitative. This study uses analysis of causal relationships, that is how one variable affects changes in other variables. To analyze the data, this study uses analysis of Structural Equation Modeling (SEM) approach Partial Least Square (PLS).In data processing using software Warp PLS. The results showed that the Accounting Information Systems Management is broadscope, timeliness, integrated, and the aggregate effect on Managerial Performance is measured using an instrument of self-rating which is reflected in four indicators, namely increased revenue, cost savings, improved customer satisfaction and increased asset utilization. This shows that although SMEs are the type of business that is not great, but still requires a wide range of information, timely, integrated and comprehensive that can assist managers in making informed decisions that impact the increase managerial performance related to efficiency-related costs but still consider satisfaction customers thus increasing the income of the SMEs in environmental conditions of uncertainty.
\end{abstract}


Keywords: SME, SIAM characteristics, Managerial Performance

\section{PENDAHULUAN}

Kedudukan usaha mikro, kecil dan menengah (UMKM) dalam perekonomian Indonesia sangat penting, hal ini dapat dilihat dari: a) kedudukannya sebagai pemain utama dalam kegiatan ekonomi di berbagai sektor, b) Penyedia lapangan kerja yang besar, c) pemain penting dalam pengembangan kegiatan ekonomi lokal dan pemberdayaan masyarakat, d) pencipta pasar baru dan inovasi, e) sumbangan dalam menjaga neraca pembayaran. Kedudukannya yang sangat penting ini menjadikan UMKM membutuhkan sistem informasi yang yang handal serta kepribadian wirausaha yang kompeten sehingga akan berdampak pada kinerja manajerial.

Informasi merupakan suatu komponen yang sangat penting bagi perusahaan karena informasi adalah input dasar dalam setiap pengambilan keputusan, oleh karena itu informasi yang relevan, tepat waktu, akurat dan lengkap sangat dibutuhkan oleh setiap perusahaan. Akuntansi manajemen merupakan jaringan penghubung yang sistematis dalam penyajian informasi yang berguna dan dapat daya untuk membantu pimpinan perusahaan dalam usaha mencapai tujuan organisasi yang telah ditetapkan sebelumnya. Informasi akuntansi manajemen dibutuhkan oleh manajemen berbagai jenjang organisasi, untuk menyusun rencana aktivitas perusahaan dimasa yang akan datang. Sistem Akuntansi Akuntansi Manajemen memiliki tiga fungsi manajemen yaitu Evaluasi pengendalian, koordinasi,dan perencanaan.

Menurut Mia dan Chenhall (1994) peranan dari sistem akuntansi manajemen dalam membantu manajer memberikan arahan serta mengatasi masalah-masalah yang timbul dalam suatu organisasi telah menyebabkan evolusi yang besar dalam implementasi sistem akuntansi manajemen (SAM). Hal ini membutuhkan data eksternal dan data bukan keuangan yang menekankan kepada pemasaran, inovasi produk, perencanaan stratejik dan informasi yang berguna untuk dalam mengambil keputusan. Semakin tingginya tingkat persaingan di pasaran perdagangan yang disebabkan oleh penggunaan teknologi produksi yang modern, deregulasi ekonomi dan penswastaan perusahaan-perusahaan yang dimiliki oleh pemerintah, menyebabkan para pengambil keputusan merasakan bahwa penggunaan SAM sangat penting (Bromwich, 1990). Di samping persaingan yang bersifat global, perkembangan produk dan teknologi proses, turun naik nilai mata uang dan perubahan-perubahan harga bahan mentah juga merupakan faktor-faktor penting dalam mempertimbangkan penerapan SAM. Hal ini disebabkan oleh SAM dapat menyediakan informasi yang terbaru serta mampu mengikuti perkembangan keadaan perdagangan yang sedang berlangsung.

Informasi sistem akuntansi yang andal menurut Chenhall dan Morris (1986) adalah yang memiliki karakteristik broad scope, timeliness, aggregation dan integration. Broad Scope mencakup informasi mengenai permasalahan baik ekonomi maupun non ekonomi, estimasi kejadian yang mungkin terjadi dimasa serta aspekaspek lingkungan. Timeliness merupakan informasi yang menunjukkan rentang waktu 
antara permohonan informasi dengan penyajian informasi yang diinginkan. Informasi yang disajikan harus tepat waktu artinya informasi tersebut harus tersedia untuk dijadikan pertimbangan dalam pengambilan keputusan sebelum informasi tersebut kehilangan kemampuan untuk mempengaruhi keputusan. Agregation merupakan informasi yang menerapkan bentuk kebijakan formal seperti discounted cash flow, analisis cost-volume-profit yang didasarkan pada area fungsional seperti pemasaran dan produksi. Integration mencakup aspek seperti ketentuan target atau aktivitas yang dihitung dari proses interaksi antar sub unit dalam organisasi.

Kebutuhan informasi dalam suatu perusahaan tergantung pada berbagai faktor. Hal ini sejalan dengan pendekatan kontijensi bahwa tingkat ketersediaan dari masing masing karakteristik informasi sistem akuntansi mungkin tidak selalu sama untuk setiap organisasi tetapi ada faktor lainnya yang akan mempengaruhi tingkat kebutuhan terhadap informasi akuntansi manajemen. Fakor-faktor tersebut antara lain ketidakpastian lingkungan, kompleksitas teknologi (Chenhall dan Morris, 1986), task uncertainty (Chong, 1996), strategi uncertainty, dan strategi.

Dalam upaya meningkatkan kinerjanya maka UMKM membutuhkan sistem informasi yang handal seperti yang telah dikemukakan diatas. UMKM mempunyai peran yang strategis dalam pembangunan ekonomi nasional, oleh karena selain berperan dalam pertumbuhan ekonomi dan penyerapan tenaga kerja juga berperan dalam pendistribusian hasil-hasil pembangunan. Krisis ekonomi yang terjadi di negara kita sejak beberapa waktu yang lalu, dimana banyak usaha berskala besar yang mengalami stagnasi bahkan berhenti aktivitasnya, sektor Usaha Kecil dan Menengah (UKM) terbukti lebih tangguh dalam menghadapi krisis tersebut. UMKM harus mendapat dukungan dari banyak pihak. Salah satu faktor pendukung selain fasilitas pembiayaan dan pelatihan oleh pemerintah, dukungan dari faktor teknologi informasi juga mendapat perhatian khusus, terutama untuk menggaet minat pasar terhadap industri dalam negeri. Penerapan teknologi banyak memberikan manfaat dalam usaha. Apabila mengerti jenis teknologi yang di perlukan maka teknologi dapat menjadi sarana percepatan usaha anda dan membuka banyak peluang. Hal inilah yang membuat UMKM membutuhkan informasi yang broad scope, timeliness, aggregation dan integration. Dengan makin besarnya skala operasi UMKM maka semakin membutuhkan teknologi informasi yang mampu memproses data (database), perencanaan sumber daya perusahaan, pengelolaan persediaan barang, pengelolaan data penjualan dan konsumen, serta lainnya.

Melihat paparan tersebut diatas, maka motivasi dari penelitian ini adalah menganalisis pengaruh penggunaan informasi akuntansi manajemen berupa broad scope, timeliness, aggregation dan integration terhadap kinerja manajerial UMKM yang ada di desa Wedoro, Kab. Sidoarjo. Berdasarkan latar belakang di atas maka rumusan masalah yang diusulkan dalam penelitian ini adalah apakah Sistem Informasi Akuntansi Manajemen yang bersifat broad scope, timeliness, integrated, dan aggregated berpengaruh terhadap kinerja manajerial UMKM yang ada di desa Wedoro, Kab. Sidoarjo. 


\section{TINJAUAN PUSTAKA}

\section{Sistem Informasi Akuntansi Manajemen}

Sistem informasi akuntansi manajemen adalah suatu mekanisme pengendalian organisasi, dimana sistem akuntansi manajemen merupakan alat yang efektif dalam menyediakan informasi yang berguna untuk memprediksi konsekuensi yang mungkin terjadi dari berbagai alternatif yang dapat dilakukan. Sistem informasi akuntansi manajemen merupakan cerminan dari fungsi perencanaan manajemen yaitu memberikan informasi untuk pengambilan keputusan, memotivasi perilaku manajer dan sebagai alat meningkatkan efisiensi (Belkaoui, 1980 dalam Jaryanto, 2008: 16).

Atkinson (1995) mengungkapkan bahwa akuntansi manajemen menghasilkan informasi yang berguna untuk membantu para pekerja, manajer dan eksekutif dalam membuat keputusan yang lebih baik. Secara tradisional informasi akuntansi manajemen didominasi oleh informasi finansial, namun dalam perkembangannya ternyata peran informasi non finansial juga menentukan output yang dihasilkan dari sistem tersebut.

Sistem akuntansi manajemen juga merupakan sistem yang mengumpulkan data operasional dan finansial, memprosesnya, menyimpannya dan melaporkannya kepada pengguna, yaitu para pekerja, manajer, dan eksekutif (Desmiyawati, 2004). Dengan penjelasan diatas mengilhami Chenhall dan Morris merumuskan karakteristik Sistem Informasi Akuntansi Manajemen yang bersifat broad scope, timeliness, aggregated, dan integrated (Chenhall dan Morris, 1986).

a. Broad scope.

Informasi sistem akuntansi manajemen yang bersifat broad scope adalah informasi yang memperhatikan focus, kuantifikasi, dan time horizon. Focus merupakan informasi yang berhubungan dengan informasi yang berasal dari dalam dan luar organisasi (faktor ekonomi, teknologi, dan pasar).

Pada dasarnya manajer membutuhkan informasi yang bersifat luas. Oleh sebab itu manajer membutuhkan informasi yang memiliki karakteristik broad scope. Karakteristik ini memiliki tiga sub dimensi antara lain fokus, kuantifikasi dan waktu. Fokus berkaitan dengan informasi yang berasal dari dalam atau luar organisasi, kuantifikasi berkaitan dengan informasi keuangan dan non keuangan, dan waktu berkaitan dengan estimasi peristiwa yang akan terjadi di masa datang.

Pada kondisi struktur organisasi desentralisasi akan mendorong manajer untuk mengembangkan kompetensinya di dalam perusahaan yang secara langsung mengarahkan mereka ke peningkatan kerja. Untuk mendukung daya saing tersebut, karakteristik broad scope akan sangat dibutuhkan. Dengan demikian organisasi dengan tingkat desentralisasi yang tinggi perlu didukung oleh informasi broad scope agar berdampak semakin positif terhadap kinerja manajerial (Chia, 1995). 


\section{b. Timeliness.}

Timeliness menyatakan ketepatan waktu dalam memperoleh informasi mengenai suatu kejadian. Dimensi timeliness mempunyai dua subdimensi yaitu frekuensi pelaporan dan kecepatan membuat laporan. Karakteristik timeliness memiliki dua sub dimensi yaitu frekuensi pelaporan dan kecepatan pelaporan. Frekuensi berkaitan dengan seberapa sering informasi disediakan untuk manajer, sedangkan kecepatan berkaitan dengan tenggang waktu antara kebutuhan akan informasi dengan tersedianya informasi. Informasi yang tepat waktu mampu mempengaruhi kemampuan manajer dalam merespon suatu peristiwa atau permasalahan. Informasi tepat waktu juga akan mendukung manajer menghadapi ketidakpastian lingkungan yang terjadi dalam organisasi (Gordon dan Narayanan, 1984). Chia (1995) menyatakan bahwa tingkat desentralisasi yang tinggi perlu didukung dengan informasi yang tepat waktu. Pada tingkat desentralisasi yang tinggi informasi yang tepat waktu akan berpengaruh positif terhadap kinerja manajer karena mampu merespon suatu kejadian dengan cepat.

\section{c. Aggregated.}

Informasi disampaikan dalam bentuk yang lebih ringkas tetapi tetap mencakup hal-hal penting sehingga tidak mengurangi nilai informasi itu sendiri. Dimensi aggregate merupakan ringkasan informasi menurut fungsi, periode waktu, dan model keputusan. Karakteristik ini merupakan ringkasan informasi menurut fungsi, periode waktu dan model keputusan. Informasi menurut fungsi akan menyediakan informasi berkaitan dengan keputusan dari unit-unit bisnis lain. Informasi yang dihasilkan ini dapat mengurangi atau menghemat waktu dalam pengambilan keputusan karena informasi telah dikumpulkan dan disusun menurut fungsi dan jangka waktu yang berbeda-beda (Ritonga, 2001).

Bagi organisasi desentralisasi, para manajer membutuhkan informasi yang berkaitan dengan area atau unit bisnis yang menjadi tanggung jawab mereka. Informasi dengan karakteristik aggregation akan mengurangi terjadinya konflik (Chenhall dan Morris, 1986) karena pada informasi ini dijelaskan mengenai area tanggung jawab fungsional masing-masing manajer.

\section{d. Integrated.}

Informasi yang mencerminkan kompleksitas dan saling keterkaitan antara bagian satu dan bagian lain. Informasi terintegrasi mencerminkan adanya koordinasi antara segmen subunit satu dan lainnya dalam organisasi. Informasi yang terintegrasi berperan sebagai koordinator dalam mengendalikan pengambilan keputusan yang beraneka ragam (Chia,1995). Manfaat informasi yang terintegrasi dirasakan penting pada saat manajer dihadapkan dengan situasi dimana harus mengambil keputusan yang mampu berdampak pada bagian/unit lain. Semakin banyak jumlah segmen dan unit bisnis dalam organisasi akan semakin besar kebutuhan informasi karakteristik integrasi dari sistem informasi akuntansi manajemen. Dengan kata lain informasi 
terintegrasi memberikan peran pengkoordinasian dalam beragam keputusan pada organisasi yang sangat terdesentralisasi.

\section{Kinerja Manajerial}

Keberhasilan suatu organisasi dalam mencapai tujuan sebagian besar tergantung pada kinerja manajer. Kinerja manajerial dapat diukur setelah sistem informasi akuntansi manajemen dapat dilaksanakan dan diaplikasikan di dalam sebuah organisasi. Kinerja manajerial tercapai apabila organisasi secara keseluruhan, atau para manajer unit bisnis secara bersama-sama mampu melakukan tugas-tugasnya dengan baik sehingga organisasi mampu mencapai sasaran dan tujuan yang telah ditetapkan.

Kinerja manajerial dapat dijelaskan sebagai bentuk eksistensi dimana manajer sudah menyelesaikan pekerjaan mereka seefektif mungkin. Evaluasi atas kinerja yang dilakukan oleh manajer beragam, tergantung pada budaya yang dikembangkan oleh masing-masing perusahaan. Kinerja manajerial merupakan persepsi kinerja individual para individu anggota organisasi dalam kegiatan-kegiatan manajerial, antara lain perencanaan, investigasi, koordinasi, supervisi, evaluasi, pengaturan staf, negosiasi dan representasi. Sejalan dengan hal itu, Mahoney (1986) dalam Atria Maharani (2010: 20-21) berpendapat bahwa terdapat delapan penilaian manajerial personal dan satu dimensi kinerja secara keseluruhan yang meliputi:

1. Kinerja Perencanaan

Menentukan tujuan, kebijakan, tindakan atau pelaksanaan, penjadwalan kerja, penganggaran, perencanaan dan pemrograman.

2. Kinerja Investigasi

Mengumpulkan dan menyiapkan informasi untuk catatan, laporan mengukur hasil, serta menganalisis pekerjaan.

3. Kinerja Pengkoordinasian

Tukar menukar informasi dengan bagian lain, untuk menyusun suatu program dan hubungannya dengan manajer lain.

4. Kinerja Evaluasi

Menilai dan mengukur keputusan yang diambil, pemeriksaan laporan keuangan dan pelayanan kepada pemakai jasa komunikasi

5. Kinerja Pengawasan

Mengarahkan, memimpin, membimbing, menjelaskan segala aturan yang berlaku, memberikan dan menangani keluhan pelaksanaan tugas bawahan.

6. Kinerja Pengaturan Staff

Mempertahankan angkatan kerja di bagiannya, merekrut, menempatkan, mempromosikan dan memutasi pegawai.

7. Kinerja Negosiasi

Melakukan kinerja manajerial atau melakukan suatu kontrak perjanjian untuk barang maupun jasa, pembelian dan tawar menawar. 


\section{Kinerja Perwakilan}

Melakukan pertemuan dengan wakil dari perusahaan-perusahaan lain dan mempromosikan tujuan umum perusahaan.

\section{Penelitian Terdahulu}

Penelitian yang dilakukan oleh Chia (1995) mengenai hubungan antara desentralisasi, karakteristik sistem informasi akuntansi manajemen dan pengaruhnya terhadap kinerja manajerial menunjukkan bahwa desentralisasi secara signifikan mampu menjembatani tingkat kemajuan masing-masing karakteristik sistem akuntansi manajemen dalam mempengaruhi kinerja organisasi. Sampel dipilih secara acak dari The Business Listing 1990 of The Telecommunications Authority of Singapore. Empat puluh delapan kuesioner digunakan dalam analisis akhir penelitian tersebut.

Ritonga (2001) melakukan penelitian terhadap 158 chief executive officers (CEO) perusahaan manufaktur di Jakarta, Tangerang, Bogor dan Karawang. Penelitian ini mengkaji pengaruh persepsi ketidakpastian lingkungan terhadap sistem informasi akuntansi manajemen yang dimoderasi oleh desentralisasi. Hasilnya menunjukkan bahwa persepsi ketidakpastian lingkungan berpengaruh terhadap sistem informasi akuntansi manajemen yang dimoderasi oleh struktur organisasi yang terdesentralisasi. Sedangkan Desmiyawati (2010) dalam penelitiannya pada manajer perbankan di Pekanbaru, membuktikan bahwa pengaruh desentralisasi terhadap kinerja manajerial mampu dimediasi oleh penggunaan sistem akuntansi manajemen dalam pengambilan keputusan.

Penelitian di bidang sistem informasi akuntansi manajemen dilakukan juga oleh Fazli dan Lilis (2006) terhadap industri minyak, pupuk dan semen di Nangroe Aceh Darussalam. Hasil dari penelitian tersebut menunjukkan bahwa sistem informasi akuntansi manajemen dengan karakteristik broad scope dan aggregation berpengaruh positif dan signifikan dengan kinerja organisasi yang dimediasi oleh persepsi ketidakpastian lingkungan. Sedangkan pada penelitian Chenhall dan Morris (1986) yang dilaksanakan terhadap 68 manajer dari 36 perusahaan manufaktur di Sydney, menunjukkan adanya hubungan positif antara ketidakpastian lingkungan dan kebutuhan informasi.

Penelitian ini diharapkan dapat menghasilkan informasi tentang pengaruh sistem informasi akuntansi manajemen yang bersifat broad scope, timeliness, aggregation dan integration terhadap kinerja manajerial UMKM di desa Wedoro, kabupaten Sidoarjo.

\section{METODE PENELITIAN}

Jenis penelitian ini adalah penelitian kuantitatif yang akan menguji pengaruh Sistem Informasi Akuntansi Manajemen yang bersifat broad scope, timeliness, aggregation dan integration terhadap kinerja manajerial UMKM di Desa Wedoro, kabupaten Sidoarjo. Penelitian ini diharapkan akan menghasilkan informasi tentang sistem informasi akuntansi manajemen yang dapat mempengaruhi kinerja manajerial 
UMKM. Hal ini disebabkan UMKM di Indonesia memiliki potensi untuk berkembang pesat sehingga harus didukung dengan kinerja manajerial yang baik.

Variabel adalah sesuatu yang mempunyai nilai atau memiliki bermacammacam nilai atau segala sesuatu yang menjadi obyek pengamatan penelitian (Sugiono, 2005:2). Variabel yang digunakan dalam penelitian ini adalah sistem informasi akuntansi manajemen UMKM sebagai variabel predictor/eksogen. Sedangkan variabel kriterion/endogen penelitian ini berupa kinerja manajerial UMKM.

1. Sistem informasi akuntansi manajemen.

Empat indikator sistem informasi akuntansi manajemen terdiri atas broad scope, timeliness, aggregation, integration (Chenhall dan Morris, 1986). Pengukuran variabel ini menggunakan instrumen yang dikembangkan oleh Chenhall dan Morris (1986). Instrumen terdiri atas 23 pertanyaan yang terbagi ke dalam empat karakteristik informasi akuntansi manajemen yang berbeda. Jawaban responden diukur menggunakan lima skala likert.

2. Kinerja manajerial

Kinerja manajerial yang diperoleh manajer merupakan salah satu faktor yang dapat dipakai untuk meningkatkan efektifitas organisasi. Karena organisasi pada dasarnya dijalankan oleh manusia, maka penilaian kinerja sesungguhnya merupakan penilaian atas perilaku manusia dalam melaksanakan peranan mereka dalam organisasi. Variabel diukur menggunakan instrumen self-rating yang dikembangkan oleh Mahoney et al. (1963). Instrumen ini terdiri dari delapan dimensi personal (perencanaan, investigasi, koordinasi, evaluasi, pengawasan, staf, negosiasi dan perwakilan) dan satu dimensi kerja secara menyeluruh (evaluasi kinerja). Sampel yang digunakan dalam penelitian ini adalah 52 UKM yang ada di desa Wedoro, Kabupaten Sidoarjo.

Penelitian ini merupakan penelitian kuantitatif. Penelitian kuantitatif menekankan pada pengujian teori-teori melalui pengukuran variabel-variabel penelitian dengan angka dan melakukan analisis data dengan prosedur statistik. Penelitian ini menggunakan analisis hubungan kausal, yaitu bagaimana satu variabel mempengaruhi perubahan-perubahan dalam variabel lainnya. Untuk menganalisis data, penelitian ini menggunakan analisis Structural Equation Modeling (SEM) dengan pendekatan Partial Least Square (PLS). Dalam pengolahan data menggunakan software WarpPLS. Analisis statistik SEM berbasis PLS digunakan untuk menjawab permasalahan serta menguji hipotesis dalam penelitian ini.

\section{HASIL DAN PEMBAHASAN}

\section{Gambaran Umum Sampel Penelitian}

Penelitian ini menggunakan 52 Usaha Kecil dan Menengah (UKM) yang ada di desa Wedoro, Sidoarjo sebagai sampel dalam penelitian ini. Jenis usaha UKM yang menjadi sampel dalam penelitian ini ada yang bergerak di bidang jasa dengan membuka jasa pendidikan. Selain itu ada juga UKM yang bergerak di bidang dagang 
dengan menjual makanan dan minuman, pakaian, dan barang-barang kebutuhan rumah tangga.

\section{Variabel Prediktor/Eksogen}

Dalam penelitian ini menggunakan variable eksogen berupa sistem informasi akuntansi manajemen yang dijelaskan oleh empat indicator terdiri atas broad scope, timeliness, aggregation, integration. Indikator sistem akuntansi manajemen yang bersifat broad scope adalah informasi yang memperhatikan focus, kuantifikasi, dan time horizon. Timeliness menyatakan ketepatan waktu dalam memperoleh informasi mengenai suatu kejadian. Dimensi timeliness mempunyai dua subdimensi yaitu frekuensi pelaporan dan kecepatan membuat laporan. Dimensi aggregate merupakan ringkasan informasi menurut fungsi, periode waktu, dan model keputusan. Integrated mencerminkan kompleksitas dan saling keterkaitan antara bagian satu dan bagian lain.

Pengukuran indikator variabel ini menggunakan instrumen yang terdiri atas 23 pertanyaan yang terbagi ke dalam empat indicator sistem informasi akuntansi manajemen yang berbeda. Jawaban responden diukur menggunakan lima skala likert. Hasil penelitian disajikan dalam tabel 1 .

Tabel 1. Deskripsi Variabel Sistem Informasi Akuntansi Manajemen

\begin{tabular}{llccccc}
\hline \multicolumn{1}{c}{\begin{tabular}{c} 
Indikator \\
\multicolumn{1}{c}{ SIAM }
\end{tabular}} & $\mathbf{1}$ & $\mathbf{2}$ & $\mathbf{3}$ & $\mathbf{4}$ & $\mathbf{5}$ & renilaian Responden \\
\hline Broadscope & 0 & 0 & 4 & 28 & 20 & 4.3 \\
Timeliness & 0 & 0 & 21 & 25 & 6 & 3.7 \\
Integrated & 0 & 0 & 16 & 14 & 22 & 4.1 \\
Aggregate & 0 & 0 & 1 & 37 & 14 & 4.2 \\
Rata-rata & 0 & 0 & 0.6 & 2 & 1.5 & 4.1 \\
\hline Sumber:
\end{tabular}

Sumber: data diolah peneliti

Berdasarkan tabel 1. terlihat bahwa Rata-rata nilai indikator broad scope menunjukkan angka 4.3. Ini berarti bahwa secara mayoritas UKM yang menjadi sampel penelitian ini sangat setuju bahwa sangat penting informasi berasal dari dalam atau luar organisasi, baik itu yang berkaitan dengan informasi keuangan dan non keuangan. Informasi berkaitan dengan keuangan dan non keuangan yang berasal baik dari dalam atau luar usaha merupakan indikator SIAM berupa broad scope.

Sedangkan berkaitan dengan indikator timeliness yang menyatakan ketepatan waktu dalam memperoleh informasi mengenai suatu kejadian menunjukkan angka 3.7. adapun dimensi timeliness mempunyai dua subdimensi yaitu frekuensi pelaporan dan kecepatan membuat laporan. Sehingga angka 3.7 berarti bahwa UKM yang menjadi sampel penelitian ini cukup sering dan cepat dalam penyusunan laporan manajerial. 
Indikator berikutnya dimensi aggregate yang menyediakan informasi berkaitan dengan keputusan dari unit-unit bisnis lain. Sehingga informasi ini dapat menghemat waktu dalam pengambilan keputusan. Tabel 1 menunjukkan bahwa ratarata nilai aggregate adalah 4.1. ini berarti bahwa responden penelitian ini menyatakan bahwa informasi yang diperoleh dari unit bisnis lain dapat membuat mereka lebih cepat dalam mengambil keputusan.

Indikator SIAM yang terakhir adalah integrated yang mencerminkan adanya koordinasi antara segmen subunit satu dan lainnya dalam organisasi. Hasil penelitian menunjukkan rata-rata nilai sebesar 4.2. angka ini berarti bahwa responden UKM sangat setuju perlunya koordinasi antar segmen sub unit dalam usaha mereka.

\section{Variabel Kriterion/Endogen}

Penelitian ini menggunakan kinerja manajerial sebagai variabel endogen. Suatu organisasi dijalankan oleh manusia, maka penilaian kinerja sesungguhnya merupakan penilaian atas perilaku manusia dalam melaksanakan peranan mereka dalam organisasi. Variabel kinerja manajerial diukur menggunakan instrumen selfrating yang dicerminkan dalam 4 (empat) indikator, yaitu peningkatan pendapatan (kk1), penghematan biaya ( $\mathrm{kk} 2$ ), peningkatan kepuasan pelanggan ( $\mathrm{kk} 3$ ) dan peningkatan penggunaan aset $(\mathrm{kk} 4)$.

Hasil penelitian sebagaimana disajikan dalam tabel 2 bahwa instrumen untuk mengukur kinerja manajerial terdiri atas 4 indikator antara lain: kk1, kk2, kk3, dan kk4. Berdasarkan tabel 2 dapat diketahui bahwa rata-rata UKM menyatakan setuju bahwa pengelola harus mampu meningkatkan pendapatan usaha serta menghemat pengeluaran biaya. Selain itu pengelola UKM juga harus mampu memberikan kepuasan kepada pelanggan serta mengoptimalkan penggunaan asset usaha.

\section{Tabel 2. Deskripsi Variabel Kinerja Manajerial}

\begin{tabular}{lcccccc}
\hline Indikator KM & \multicolumn{9}{c}{ Penilaian Responden } & Rata- \\
\cline { 2 - 6 } & $\mathbf{1}$ & $\mathbf{2}$ & $\mathbf{3}$ & $\mathbf{4}$ & $\mathbf{5}$ & rata \\
\hline kk1 & 0 & 0 & 3 & 24 & 25 & 4.42 \\
kk2 & 0 & 0 & 2 & 24 & 26 & 4.46 \\
kk3 & 0 & 1 & 2 & 23 & 26 & 4.42 \\
kk4 & 0 & 1 & 1 & 20 & 30 & 4.52 \\
Rata-rata & 0 & 0.01 & 0.12 & 1.75 & 2.57 & 4.45 \\
\hline
\end{tabular}

Sumber: data diolah peneliti

\section{Hasil Pengujian WarpPLS}

Penelitian ini menguji pengaruh variabel eksogen Sistem Informasi Akuntansi Manajemen: terhadap variabel endogen kinerja manajerial. Penelitian ini dikonstruksi dengan menggunakan bantuan software Warp-PLS. Berikut hasil pengujian menggunakan software Warp-PLS: 
1. Output Path coefficients and $P$ values

Output ini menyajikan hasil estimasi koefisien jalur (path coefficient) dan nilai p. tabel 4. menyajikan output ini. Berdasarkan tabel 4 dapat dijelaskan bahwa kolom menunjukkan variabel laten predictor dan baris menunjukkan variabel laten kriterion. Dalam tabel 4 terlihat bahwa koefisien jalur pengaruh Sistem Informasi Akuntansi Manajemen (SIAM) terhadap Kinerja Manajerial (KM) adalah sebesar 0,389 dan signifikan pada 0,001. Ini berarti 1 variasi dari deviasi standar SIAM menyebabkan 0,389 variasi deviasi standar Kinerja Manajerial.dalam Warp-PLS, outputnya merupakan variable yang telah distandarisasi.

Tabel 4. Output Path coefficients and $P$ values

\begin{tabular}{lcc}
\hline \multicolumn{3}{c}{ Path coefficients } \\
\hline \multicolumn{3}{c}{ SIAM KM } \\
SIAM \\
KM & 0.389 \\
\hline \multicolumn{3}{c}{ P values } \\
\hline \multicolumn{3}{c}{ SIAM KM } \\
SIAM & & \\
KM & $<0.001$ \\
\hline
\end{tabular}

Sumber: data diolah peneliti

2. Output Combined loadings and Cross-loadings

Output Combined loadings and Cross-loadings untuk menjelaskan hasil pengujian validitas konvergen dari instrument pengukuran (kuisioner). Validitas konvergen merupakan bagian dari pengukuran model yang dalam SEM-PLS biasanya disebut sebagai outer model. Output ini menampilkan konstruk pada kolom dan indikator-indikatornya pada baris. Output ini disajikan dalam tabel 5.

Tabel 5 Output Combined loadings and Cross-loadings

\begin{tabular}{lrrl}
\hline & SIAM & \multicolumn{1}{l}{ KM } & P value \\
\hline bs & $\mathbf{0 . 8 3 9}$ & -0.093 & $<0.001$ \\
tl & $\mathbf{0 . 6 5 7}$ & 0.061 & $<0.001$ \\
int & $\mathbf{0 . 6 8 6}$ & 0.255 & $<0.001$ \\
agg & $\mathbf{0 . 6 7 8}$ & -0.203 & 0.004 \\
kk1 & 0.186 & $\mathbf{0 . 8 4 5}$ & $<0.001$ \\
kk2 & -0.161 & $\mathbf{0 . 8 5 5}$ & $<0.001$
\end{tabular}




\begin{tabular}{llll}
$\mathrm{kk} 3$ & -0.019 & $\mathbf{0 . 9 5 6}$ & $<0.001$ \\
$\mathrm{kk} 4$ & -0.002 & $\mathbf{0 . 8 8 4}$ & $<0.001$ \\
\hline
\end{tabular}

Note: $\mathrm{P}$ values $<0.05$ are desirable for reflective indicators.

Sumber: data diolah peneliti

Tabel 5 menunjukkan bahwa kosntruk SIAM diukur dengan indikator bs, tl, int, dan agg. Loading setiap indikator pada konstruknya diberi tanda kurung serta terdapat nilai p-nya. Sebagaimana terlihat dalam tabel 4.5 bahwa nilai loading untuk indikator SIAM: broadscope (bs) sebesar 0,839 dan signifikan dengan nilai $\mathrm{p}<0.001$; timeliness $(\mathrm{tl})$ sebesar 0,657 dan signifikan dengan nilai $\mathrm{p}<0.001$; integrated (int) sebesar 0,686 dan signifikan dengan nilai $\mathrm{p}<0.001$; serta aggregate (agg) sebesar 0,678 dan signifikan dengan nilai $\mathrm{p}=0.004$. Menurut Hair, dkk (2013) dalam Sholihin dan Ratmono (2013:65) bahwa terdapat dua kriteria untuk menilai apakah outer model memenuhi syarat validitas konvergen untuk konstruk reflektif yaitu (1) loading harus di atas 0,70 dan (2) nilai p signifikan $(\mathrm{p}<0.05)$. Namun dalam beberapa kasus, seperti halnya dalam penelitian ini bahwa kuisioner baru dikembangkan bahwa indicator dengan loading antara 0.40-0.70 sebaiknya dianalisis dampak dari keputusan menghapus indicator tersebut pada nilai Average Variance Extracted (AVE) dan Composit Reliability. Apabila indicator dengan nilai loading tersebut menghasilkan nilai keduanya di bawah batasannya maka indikator tersebut tetap dipertimbangkan untuk dipertahankan. Sehingga berdasarkan penjelasan ini maka pengukuran konstruk SIAM telah memenuhi syarat validitas konvergen karena memiliki nilai loading di atas 0,40 .

Selain itu dalam melihat output ini perlu memperhatikan hasil cross-loading yang menunjukkan nilai loading ke konstruk lain. Nilai cross loading diharapkan lebih rendah daripada ke konstruk tersebut. Berdasarkan tabel 5 dapat terlihat bahwa nilai loading indicator bs ke konstruk SIAM menunjukkan angka 0.839. nilai ini lebih besar dibandingkan nilai cross-loading bs ke konstruk KM yang menunjukkan angka -0,093. Demikian juga untuk nilai loading indicator kk1 ke konstruk KM sebesar 0.845 lebih besar dibandingkan nilai cross-loading kk1 ke konstruk SIAM sebesar 0,186. Hasil cross-loading mengindikasikan terpenuhinya kriteria validitas diskriminan.

3. Output Latent Variable Coefficients

Output Latent Variable Coefficients merupakan salah satu yang terpenting karena menyajikan berbagai hasil estimasi yang wajib dilaporkan dalam karya ilmiah. Beberapa hasil yang ditampilkan antara lain koefisien determiansi, reliabilitas instrument, validitas diskriminan, full colliniearity test, dan validitas prediktif. Koefisien determinasi menggunakan $R$-squared menunjukkan berapa prosentase variansi konstruk endogen/criterion dapat dijelaskan oleh konstruk eksogen/prediktor. Berdasarkan tabel 5. nilai R-squared konstruk Kinerja 
Manajerial sebesar 0,151. Ini menunjukkan bahwa variansi kinerja manajerial dapat dijelaskan sebesar $15,1 \%$ oleh variansi sistem infomasi akuntansi manajemen. Sedangkan $Q$-squared digunakan untuk penilaian validitas prediktif atau relevansi dari sekumpulan variable laten predictor pada variable kriterion. Model denngan validitas prediktif harus mempunyai nilai $Q$-squared lebih besar dari nol. Tabel 5. menunjukkan bahwa hasil estimasi model penelitian ini menunjukkan validitas prediktif yang baik karena bernilai di atas nol yaitu sebesar 0,169.

Output ini juga menyajikan ukuran reliabilitas instrumen penelitian yaitu composite reliability. Tabel 5 menyajikan bahwa reliabilitas instrumen telah terpenuhi karena nilai composite reliability SIAM sebesar 0,809 dan KM sebesar 0,936 yang berarti nilai tersebut di atas 0,70 . Sedangkan nilai AVE digunakan untuk evaluasi validitas konvergen. Kriterianya harus di atas 0,50. Berdasarkan tabel 5 tersaji untuk nilai AVE sebesar 0,517 untuk SIAM dan 0,785 untuk KM. ini berarti bahwa nilai AVE konstruk penelitian ini di atas 0,50 sehingga validitas konvergen terpenuhi.

Tabel 5 juga menampilkan output full colinearity VIFs yang merupakan hasil pengujian kolinearitas penuh yang meliputi multikolinearitas vertical dan lateral (kolinearitas antara variable laten eksogen dan endogen). Output full colinearity VIFs dalam penelitian ini menghasilkan nilai 1,151 . Nilai ini lebih rendah dari 3,3 sehingga model bebas multikolinearitas vertical maupun lateral serta commom method bias.

\section{Pembahasan}

Hasil penelitian menunjukkan bahwa Sistem Informasi Akuntansi Manajemen berpengaruh terhadap Kinerja Manajerial. Hal ini disebabkan secara keseluruhan UMKM yang menjadi sampel dalam penelitian ini menyatakan bahwa yang dibutuhkan adalah informasi yang bersifat broadscope, timeliness, integrated, dan aggregate.

Informasi bersifat broadscope atau luas artinya informasi yang dibutuhkan oleh UMKM di Desa Wedoro Kabupaten Sidoarjo adalah informasi yang bukan hanya tentang pemasok lokal bahan baku. Dalam melaksanakan tugasnya manajer membutuhkan informasi dari berbagai sumber yang sifatnya luas. Karena itu manajer UMKM membutuhkan informasi yang memiliki karakteristik broadscope yaitu informasi yang memiliki cakupan yang luas dan lengkap (completeness). Informasi tersebut diantaranya yang berhubungan dengan kejadian di masa yang akan datang sehingga mendukung UMKM melakukan inovasi. Selain itu informasi yang dibutuhkan juga berkaitan dengan factor eksternal perusahaan seperti kondisi ekonomi, pertumbuhan penduduk, dan perkembangan teknologi. Informasi yang bersifat luas juga meliputi aspek non finansial seperti: efisiensi mesin, absen karyawan, tingkat kerusakan produk, serta pangsa pasar. Informasi non-ekonomis misalnya: selera pelanggan, sikap karyawan, relasi kerja, sikap pemerintah serta ancaman pesaing sangat diperlukan oleh UMKM. 
Tabel 6. Output Latent Variable Coefficients

\begin{tabular}{|c|c|c|}
\hline \multicolumn{3}{|c|}{ R-squared coefficients } \\
\hline \multirow[t]{2}{*}{ SIAM } & \multicolumn{2}{|c|}{ KM } \\
\hline & & 0.151 \\
\hline \multicolumn{3}{|c|}{ Composite reliability coefficients } \\
\hline \multirow[t]{2}{*}{ SIAM } & \multicolumn{2}{|c|}{ KM } \\
\hline & 0.809 & 0.936 \\
\hline \multicolumn{3}{|c|}{ Average variances extracted } \\
\hline \multirow[t]{2}{*}{ SIAM } & \multicolumn{2}{|c|}{$\mathrm{KM}$} \\
\hline & 0.517 & 0.785 \\
\hline \multicolumn{3}{|c|}{ Full collinearity VIFs } \\
\hline \multirow[t]{2}{*}{ SIAM } & \multicolumn{2}{|c|}{ KM } \\
\hline & 1.151 & 1.151 \\
\hline \multicolumn{3}{|c|}{ Q-squared coefficients } \\
\hline \multirow[t]{2}{*}{ SIAM } & & \\
\hline & & 0.169 \\
\hline
\end{tabular}

Sumber: data diolah peneliti

Selain informasi yang bersifat luas, UMKM juga membutuhkan informasi yang tepat waktu (timeliness), UMKM yang menjadi sampel penelitian ini membutuhkan informasi yang mencerminkan kondisi terkini dan sesuai dengan kebutuhan manajer. Informasi yang segera ada ketika dibutuhkan serta tidak ada keterlambatan dalam penyampaian informasi (frekuensi pelaporan teratur) menjadi hal yang sangat penting bagi UMKM. Hal ini dikarenakan informasi yang tepat waktu akan membantu manajer dalam pengambilan keputusan.

Berkaitan dengan sifat terintegrasi (integrated), UMKM di desa Wedoro Kabupaten Sidoarjo memerlukan informasi yang terintegrasi dan saling berkaitan. Informasi yang berkaitan dengan penjualan mereka akan berkaitan dengan informasi barang yang akan mereka produksi dan pemasok bahan baku mereka. Karakteristik terintegrasi atau terpadu memberikan sarana koordinasi antar segmen dalam sub unit atau antar sub unit dalam organisasi. Semakin banyak jumlah segmen dan unit bisnis dalam organisasi akan semakin besar kebutuhan informasi karakteristik integrasi dan SIAM. Sehingga UMKM memerlukan informasi yang disediakan pada bagian atau wilayah fungsional yang berlainan seperti: marketing, produksi, pusat laba, dan pusat penjualan. Informasi ini mencerminkan kompleksitas dan saling keterkaitan antara 
bagian satu dan bagian lain. Manfaat informasi yang terintegrasi dirasakan penting saat manajer dihadapkan pada situasi dimana harus mengambil keputusan yang akan berdampak pada bagian/unit yang lain. Informasi yang menunjukkan pengaruh kejadian pada fungsi yang berbeda misalnya informasi dari fungsi produksi yang nantinya berdampak pada fungsi pemasaran.

Informasi yang juga sangat dibutuhkan UMKM adalah informasi yang bersifat teragregasi (aggregate). Hal ini disebabkan bahwa apabila informasi tersebut bersifat teragregasi dengan tepat akan memberikan masukan penting dalam proses pengambilan keputusan, karena waktu yang diperlukan untuk mengevaluasi informasi relatif lebih pendek dibandingkan dengan informasi yang masih bersifat parsial. Selain itu informasi yang disampaikan dalam bentuk lebih ringkas tetapi tetap mencakup hal-hal penting sehingga tidak mengurangi nilai informasi itu sendiri sangat dibutuhkan UMKM. Dikarenakan lebih sedikit waktu yang diperlukan untuk mengevaluasinya, sehingga meningkatkan efisiensi kerja manajemen. Informasi yang teragregasi memungkinkan membuat model keputusan seperti analisis aliran kas, aliran tambahan biaya, analisis persediaan, dan analisis kebijakan perusahaan. Hasil penelitian ini mendukung hasil penelitian Fazli dan Lilis (2006) bahwa system informasi akuntansi manajemen berpengaruh terhadap kinerja manajerial berkaitan dengan ketidakpastian lingkungan.

\section{SIMPULAN DAN SARAN \\ Simpulan}

Hasil penelitian menunjukkan bahwa Sistem Informasi Akuntansi Manajemen yang bersifat broadscope, timeliness, integrated, dan aggregate berpengaruh terhadap Kinerja Manajerial yang diukur menggunakan instrumen self-rating yang dicerminkan dalam 4 (empat) indikator, yaitu peningkatan pendapatan, penghematan biaya, peningkatan kepuasan pelanggan dan peningkatan penggunaan aset. Hal ini menunjukkan bahwa meskipun UMKM yang merupakan jenis usaha yang tidak besar, namun tetap membutuhkan informasi yang luas, tepat waktu, terintegrasi serta menyeluruh yang dapat membantu manajer dalam pengambilan keputusan yang tepat sehingga berdampak adanya peningkatan kinerja manajerial terkait efisiensi terkait biaya namun tetap memperhatikan kepuasan pelanggan sehingga meningkatkan pendapatan UMKM tersebut dalam kondisi lingkungan yang uncertainty.

Saran

1. Penelitian selanjutnya diharapkan dapat mengaplikasikan hasil penelitian ini pada UMKM yang berbeda dan lebih homogen dari segi jenis usaha sehingga dapat diketahui karakteristik yang lebih spesifik terkait kebutuhan informasi akuntansi manajemen.

2. Penelitian selanjutnya juga diharapkan dapat mengembangkan penggunaan pengukuran kinerja manajerial lainnya seperti perencanaan, investigasi, koordinasi, evaluasi, pengawasan, staf, negosiasi dan perwakilan. 
3. Perlu adanya pembentukan pusat layanan bagi UMKM di wilayah Wedoro sehingga memudahkan bagi UMKM wilayah tersebut dalam mengakses informasi sesuai karakteristik SIAM. 


\section{DAFTAR PUSTAKA}

Atkinson, A. A. RJ. Banker, R.S Kaplan, dan S.M Young, 1995, Management Accounting Englewood Cliffs, New Jersey, Prentice-Hall.

Bromwich, Michael, 1990, The Case for Strategic Management Accounting: The Role of Accounting Management Information for Strategy in Competitive Markets, diakses dari alamat website http://www.sciencedirect.com/science/article.

Chenhall, Robert H., and Morris, Deigen, 1986, The Impact of Structure, Enviroment, and Interdependence on the Perceived Usefulness of Management Accounting System. The Accounting Review, LXI, (1), 16-33

Chia, Y.M., 1995, "Desentralization Management Accounting System (MAS) Information Characteristic and their Interaction Effects on Managerial P. Desentralization Management Accounting System (MAS) Information Characteristic and their Interaction Effects on Managerial Performance; A Singapore Study". Journal of Business Finance and Accounting. Sept. pp 881 830.

Chong, Vincent K., 1996, Management Accounting Systems, Task Uncertainty and Managerial Performance: A Research Note, Accounting Organization and Society, Vol. 21, No. 5, pp. 415-421

Desmiyawati, 2004, Pengaruh Strategi dan Ketidakpastian Lingkungan terhadap Hubungan antara Informasi Sistem Akuntansi Manajemen Broadscope dan Kinerja Organisasi. Jurnal Akuntansi dan Bisnis, 4 (2), 94-108

Fazli, Syam dan Lilis Maryasih, 2006, "Sistem Akuntansi Manajemen, Persepsi Ketidakpastian Lingkungan, Desentralisasi, dan Kinerja Organisasi (Studi Empiris Pada Perusahaan Manufaktur Di Provinsi Nad)". Simposium Nasional Akuntansi 9, Padang

Gordon, L.A. dan V.K. Narayanan, 1984, "Management Accounting System: Perceived Environmental Uncertainty and Organisation Structure: An Empirical Investigation", Accounting, Organizations and Society, Vol.9, pp.33-47.

Jaryanto, 2008, Pengaruh Ketidakpastian Tugas dan Desentralisasi terhadap Kinerja Manajerial dengan Sistem Akuntansi Manajemen sebagai variable intervening, Tesis, diakses dari alamat website http://eprints.undip.ac.id

Mahoney, T. A., Jerdee, T. H. \& Caroll, S. J., 1963, Development of Managerial Performance: A Research Approach, Cincinnati, Ohio: South Western Publishing.

Mia, L., \& Chenhall, R. H., The Usefulness of Management Accounting Systems, Functional Differentitation and Managerial Effectiveness, Accounting, Organization and Society, pp. 1-13

Mulyadi dan Johny Setiawan, 1999, Sistem Perencanaan dan Pengendalian Manajemen: Sistem Pelipatgandaan Kinerja Perusahaan, Edisi 1, Penerbit Aditya Media, Yogyakarta. 
Rafinaldy, Neddy, 2006, Memeta Potensi dan Karakteristik UMKM Bagi Penumbuhan Usaha Baru, Infokop Nomor 29 Tahun XXII

Sekaran, U., 2003, Research Methods For Business. 4th Edition. (Kwan Men Yon,Pentj), John Wiley \& Sons Inc.

Sholihin, Mahfud dan Dwi Ratmono, 2013, Analisis SEM-PLS dengan WarpPLS 3.0, Penerbit Andi Yohyakarta.

Sugiono, 2005, Metode Penelitian Bisnis, Penerbit: CV Alphabeta Bandung.

Warren, Fees, Reeve, 2005, Pengantar Akuntansi, Edisi ke dua puluh satu, Penerbit Salemba Empat, Jakarta. 